\title{
Author Correction: Turn-key mapping of cell receptor force orientation and magnitude using a commercial structured illumination microscope
}

\author{
Aaron Blanchard, J. Dale Combs, Joshua M. Brockman, Anna V. Kellner (D), Roxanne Glazier, Hanquan Su, \\ Rachel L. Bender (D), Alisina S. Bazrafshan, Wenchun Chen, M. Edward Quach (1), Renhao Li (D,
} Alexa L. Mattheyses (1) \& Khalid Salaita (D)

Correction to: Nature Communications https://doi.org/10.1038/s41467-021-24602-x, published online 3 August 2021.

The original version of this Article omitted the following from the Acknowledgements:

J.M.B., A.T.B., and R.G. acknowledge NSF GRFP grant no. 1444932. J.M.B. acknowledges NCI fellowship grant no. F99CA234959. A.T.B. acknowledges NCI fellowship grant no. F99CA245789. A.V.K. acknowledges NIH grant no. F31 F31CA243502. M.E.Q. acknowledges NIH grant no. F31 F31HL134241. R.L. acknowledges NIH grant no. HL082808. A.L.M. and K.S. acknowledge NIH grant no. R01GM131099. A.L.M. acknowledges NSF CAREER1832100. K.S. acknowledges NIH grant no. R01GM124472.

We thank Laura Fox-Goharioon, Neil Anthony, and William Giang of the Integrated Cellular Imaging Core Facility at Emory University for maintaining and troubleshooting the SIM microscope used in this work. We also thank Eric Rentchler of the Biomedical Microscopy Core at the University of Michigan for coordinating access to software for SIM super-resolution reconstructions. We thank Rong Ma of Emory University for providing graphical illustrations. Finally, we thank Tejeshwar Rao, Reena Beggs, Tomasz Nawara, and Will Dean of the Mattheyses lab at the University of Alabama, Birmingham for helpful conversations.

This has now been corrected in both the PDF and HTML versions of the Article.

Published online: 16 September 2021

\footnotetext{
(c) (i) Open Access This article is licensed under a Creative Commons Attribution 4.0 International License, which permits use, sharing, adaptation, distribution and reproduction in any medium or format, as long as you give appropriate credit to the original author(s) and the source, provide a link to the Creative Commons license, and indicate if changes were made. The images or other third party material in this article are included in the article's Creative Commons license, unless indicated otherwise in a credit line to the material. If material is not included in the article's Creative Commons license and your intended use is not permitted by statutory regulation or exceeds the permitted use, you will need to obtain permission directly from the copyright holder. To view a copy of this license, visit http://creativecommons.org/licenses/by/4.0/.
}

(C) The Author(s) 2021 